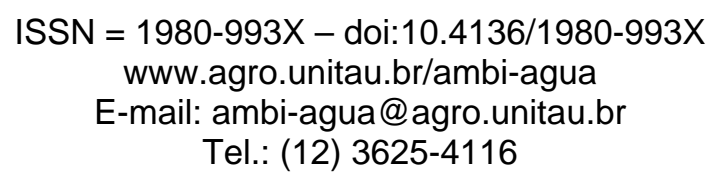

\title{
Análise espaço-temporal da cobertura do solo em faixas de áreas de preservação permanente (APPs) no município de Sorocaba, SP, Brasil
} (doi:10.4136/ambi-agua.94)

\author{
Alexandre Marco da Silva ${ }^{1}$; Felipe Muniz Silveira ${ }^{1}$; Priscila Ikematsu ${ }^{2}$; Fabíolla Pereira \\ de Paula ${ }^{3}$; Michele Bomback ${ }^{1}$; Davi Pajaro Nogueira ${ }^{4}$; Sérgio Henrique Alves ${ }^{5}$ \\ ${ }^{1}$ Universidade Estadual Paulista \\ E-mail: amsilva@sorocaba.unesp.br; felipesantista@hotmail.com; mibomback@yahoo.com.br \\ ${ }^{2}$ Instituto de Pesquisas Tecnológicas do Estado de São Paulo \\ E-mail: priike@ipt.br \\ ${ }^{3}$ Bunge Fertilizantes S/A \\ Email: fabiolla.paula@bunge.com \\ ${ }^{4}$ Secretaria de Meio Ambiente do Estado de São Paulo \\ E-mail: davip@ambiente.sp.gov.br \\ ${ }^{5}$ Companhia de Desenvolvimento dos Vales do São Francisco e do Parnaíba \\ E-mail: sergio.henrique@codevasf.gov.br
}

\section{RESUMO}

Considerando a importância fundamental que a mata ciliar possui na manutenção da qualidade ambiental de uma bacia hidrográfica e da necessidade que há em revegetar trechos desprovidos de vegetação, neste trabalho investigaram-se quais classes de cobertura do solo ocorrem nas faixas consideradas Área de Preservação Permanente (APP) no município de Sorocaba - SP em três épocas: 1988, 1995 e 2003. Por meio de técnicas de geoprocessamento, gerou-se um arquivo contendo as faixas de APP dos cursos d'água ocorrentes ao longo da área de estudo e efetuou-se a sobreposição desse mapa com os mapas de cobertura do solo. Os resultados apontam que 58,43\% do total de faixas de APPs possuem uma cobertura do solo desprovida de vegetação arbórea e que necessitam de um programa de restauração florestal, representando 5.400 hectares de APP a ser revegetado.

Palavras-chave: mapa de cobertura do solo; faixa de APP; geoprocessamento.

\section{Spatial and temporal analysis of the land cover in riparian buffer zones (Areas for Permanent Preservation) in Sorocaba City, SP, Brazil}

\begin{abstract}
Considering the fundamental role that the riparian vegetation plays in relation to maintenance of the environmental health of a watershed and the necessity of restoring sectors of the buffer zone without natural vegetation, in this paper we investigated what land cover classes occur along the riparian buffer stripes considered Area for Permanent Preservation (APP) in the Sorocaba municipality, SP in three periods: 1988, 1995 and 2003. Based on GIS technology and using the drainage network map, the APP stripes (riparian buffer zones) map was generated, and this map was overlaid to the land cover map (1988, 1995 and 2003) to provide a land cover map specifically of the riparian buffer zones. The results show that $58.43 \%$ of the APPs have no land cover of native vegetation and therefore, need to be reforested, representing 5,400 hectares to be restored.
\end{abstract}

Keywords: land cover maps; riparian buffer zones; geoprocessing. 
SILVA, A. M.; SILVEIRA, F. M.; IKEMATSU, P.; PAUlA, F. P.; BOMBACK, M.; NOGUEIRA, D. P.; ALVES, S. H. Análise espaço-temporal da cobertura do solo em faixas de áreas de preservação permanentes (apps) no município de Sorocaba, SP, Brasil. Ambi-Agua, Taubaté, v. 4, n. 2, p. 147-155, 2009. (doi:10.4136/ambi-agua.94)

\section{INTRODUÇÃO}

Conforme transita-se de um ecossistema terrestre para um ecossistema aquático, notamos a ocorrência de outro ecossistema que, segundo alguns autores (Naiman e Décamps, 1997; Paul e Meyer, 2001; Poole, 2002; Allan, 2004), caracteriza uma faixa de transição entre esses dois ecossistemas, ganhando características ecológicas peculiares devido, principalmente, ao regime hídrico dos solos e hidrológico dos cursos d'água daquela região, retornando num padrão de estrutura e funcionamento bastante particular. Daí surge o conceito de ecossistema ripário, o qual engloba as matas ciliares, estas formadas por vegetação nativa que orla um ou os dois lados de um curso d'água numa largura variável conforme as características ecológicas do curso d'água.

Devido à grande gama de serviços ecológicos que o ecossistema ripário realiza, os quais são essenciais para a manutenção da sadia qualidade ambiental de uma bacia hidrográfica e também da qualidade de vida humana (Melo et al., 2007), este é considerado um local estratégico para conservação, uma vez que a degradação desencadeia uma série de consequências ambientais locais e regionais de ordem hidrológica, sedimentológica, de biodiversidade, dentre outras.

Quanto à utilização desse espaço, os seus valores do ponto de vista do interesse de diferentes setores de uso da terra são bastante conflitantes: para o criador de gados, representam obstáculo ao livre acesso do gado à água. Para o setor de produção florestal, este localiza-se em sítios bastante produtivos, onde crescem árvores altamente interessantes economicamente. Em regiões de relevo movimentado, proporcionam as únicas alternativas para o traçado e construção de estradas. Para o abastecimento de água ou para a geração de energia, representam excelentes estratégicos de armazenamento de água visando à regularização de vazões e garantia de suprimento contínuo de água para fins consuntivos Silveira (2006).

A conservação desse ecossistema ocorre pela formulação e existência de uma legislação ambiental, que considera faixas ciliares Áreas de Preservação Permanente (APP), numa largura proporcional em relação à largura do curso d'água ou ao tamanho da lagoa, represa ou algum outro ecossistema lêntico (lei federal 4771, de 1965 do Código Florestal Brasileiro). Essa lei institui que para cursos d'água com largura de até 10 metros deve haver uma faixa de preservação permanente de pelo menos 30 metros de largura em cada lado do curso d'água. Para as nascentes, há a necessidade da manutenção de uma área, também considerada APP, num raio de 50 metros no entorno da nascente.

Inovações no gerenciamento de zonas ripárias têm sido efetivas no melhoramento de diversas questões relacionadas ao uso de solo e à qualidade ambiental. As zonas ripárias exercem funções fundamentais também na questão do planejamento de paisagens e de gerenciamento da água e na restauração de sistemas aquáticos (Naiman e Décamps, 1997).

Apesar da legislação vigente, não é raro encontrarmos ao longo dos cursos d'água que atravessam o território brasileiro, trechos de rio com a faixa de APP totalmente degradada, devido a inúmeras razões (Mattos et al., 2007). Infelizmente, o município de Sorocaba (SP) não foge a regra. Devido a um uso da terra de longa data que vem ocorrendo nesse município, é esperado que boa parte das faixas de APP estejam atualmente com a cobertura do solo alterada e seus cursos d'água impactados, havendo a necessidade da restauração dessas faixas de APP.

Uma vez estando degradada a vegetação, há a necessidade da revegetação dessa área para que o ecossistema ripário tenha condições, após algum tempo, de restabelecer ao menos parte dos "serviços" ecológicos que originalmente eram ali realizados: filtragem, regularização hídrica, manutenção da biodiversidade aquática, amenização da erosão em barrancas, dentre outras. 
SILVA, A. M.; SILVEIRA, F. M.; IKEMATSU, P.; PAULA, F. P.; BOMBACK, M.; NOGUEIRA, D. P.; ALVES, S. H. Análise espaço-temporal da cobertura do solo em faixas de áreas de preservação permanentes (apps) no município de Sorocaba, SP, Brasil. Ambi-Agua, Taubaté, v. 4, n. 2, p. 147-155, 2009. (doi:10.4136/ambi-agua.94)

A identificação de áreas carentes de vegetação pode ser feita através da investigação de mapas digitais de cobertura do solo, onde, partindo-se da hidrografia e utilizando-se técnicas de geoprocessamento, as faixas de APP são geradas e isoladas. Esse plano de informação é então sobreposto aos mapas de cobertura da área, a fim de mostrar a cobertura do solo somente nessa área de interesse, que é a faixa de APP (Narumalani et al., 1997).

A investigação da quantidade de vegetação natural remanescente em zonas ripárias constitui um método de investigação da situação ambiental da área sob a ótica da Ecologia de Paisagem, uma vez que muitas pesquisas vêm comprovando a influência da porcentagem de ocorrência desse tipo de cobertura do solo sobre a dinâmica ambiental da bacia hidrográfica a qual a área ripária pertence (Gergel et al., 2002; Allan, 2004), incluindo associações com análises da qualidade da água, taxas de erosão, integridade da biota aquática, conectividade entre fragmentos, entre outros aspectos.

Neste trabalho almejou-se saber quais classes de cobertura do solo ocorrem numa faixa de 30 metros de cada lado dos cursos d'água e também ao longo de um raio de 50 metros ao longo das nascentes existentes no município de Sorocaba - SP em três épocas: 1988, 1995 e 2003.

\section{CARACTERIZAÇÃO AMBIENTAL DA ÁREA DE ESTUDO}

O município de Sorocaba situa-se no interior do estado de São Paulo (Figura 1), entre as coordenadas $23^{\circ} 21^{\prime}$ e e $23^{\circ} 35^{\prime}$ de Latitude Sul e $47^{\circ} 17^{\prime}$ e $47^{\circ} 36^{\prime}$ de Longitude Oeste. Possui uma área de $449 \mathrm{~km}^{2}$ e uma população de aproximadamente 589.000 habitantes, sendo cerca de $98 \%$ considerada urbana (IBGE, 2007).

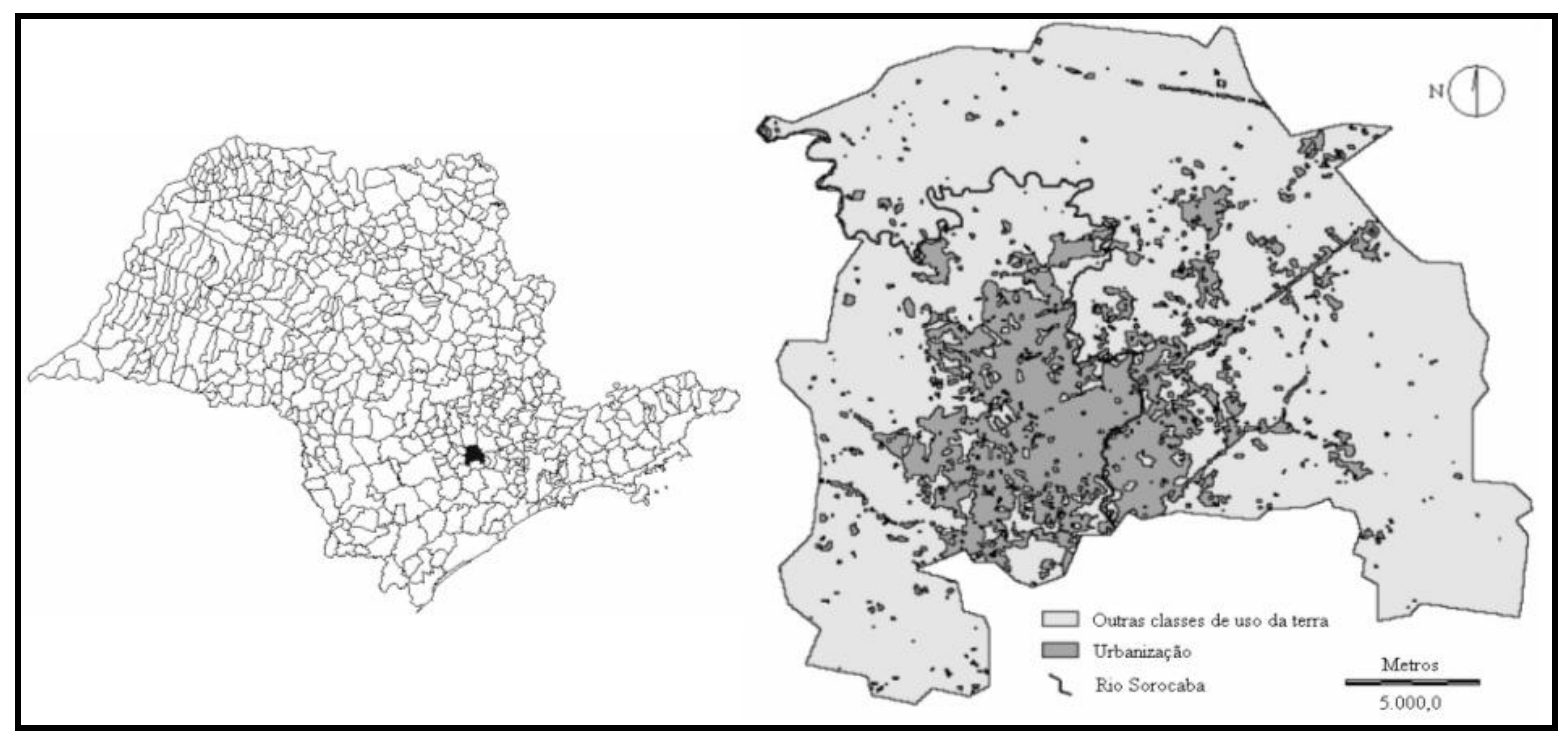

Figura 1. Localização do município de Sorocaba (SP) no estado de São Paulo (esquerda) e sua mancha urbana (direita).

Fonte: Silva (2007).

Trata-se de um município com 351 anos de existência e de grande importância no cenário socioeconômico paulista e brasileiro, sendo responsável por $1,103 \%$ do PIB paulista (Fundação Seade, 2007). Por outro lado, há uma carência de estudos ambientais que visam caracterizar os ambientes físico, biológico e antrópico, os quais podem prestar efetiva colaboração num planejamento de uso e ocupação do solo disciplinado e sustentável, tanto no meio urbano como também no meio rural.

O clima da região é, segundo classificação de Köeppen, do tipo “Cfa” (subtropical quente), tendo como temperatura média anual $21,4^{\circ} \mathrm{C}$, máxima de verão $30,1^{\circ} \mathrm{C}$ e mínima de 
SILVA, A. M.; SILVEIRA, F. M.; IKEMATSU, P.; PAULA, F. P.; BOMBACK, M.; NOGUEIRA, D. P.; ALVES, S. H. Análise espaço-temporal da cobertura do solo em faixas de áreas de preservação permanentes (apps) no município de Sorocaba, SP, Brasil. Ambi-Agua, Taubaté, v. 4, n. 2, p. 147-155, 2009. (doi:10.4136/ambi-agua.94)

inverno $12,2^{\circ} \mathrm{C}$ e, ainda, $1.285 \mathrm{~mm}$ de altura pluviométrica anual (Embrapa, 2007). Na região, ocorrem solos pertencentes predominantamente às classes Argissolos e Latossolos, embora ocorram também Cambissolos, Neossolos litólicos e Gleissolos em algumas porções do município (Oliveira et al., 1999).

Sorocaba localiza-se numa faixa onde há o predomínio do bioma denominado Floresta Atlântica, embora algumas manchas de Cerrado também ocorrem, com nível de degradação bastante variável conforme a região do município.

Cerca de $80 \%$ da área do município de Sorocaba é considerada imprópria para o estabelecimento de espécies silvestres e considera-se que há necessidade urgente de uma reorganização territorial em algumas regiões, objetivando a instalação de corredores de biodiversidade para evitar o isolamento total de alguns fragmentos considerados "habitats primários” (Silva, 2007). Ainda, segundo o mesmo autor, a recuperação de florestas ripárias ao longo dos cursos d'água seria um caminho provavelmente bem sucedido.

Segundo Silveira (2006), há em Sorocaba 1.198 km de cursos d’água e 2.332 nascentes (Figura 2). Sua distribuição não é uniforme ao longo da área de estudo devido, principalmente, ao embasamento geológico ser diferenciado ao longo da área de estudo, bem como o relevo não uniforme ao longo do município.

\section{PROCEDIMENTOS}

O trabalho foi desenvolvido por meio de técnicas de geoprocessamento, sendo o software Idrisi (Eastman, 2004) o principal recurso utilizado. Como base de dados utilizaramse os mapas digitais de hidrografia e de nascentes, já apresentados na Figura 2 e os mapas de cobertura do solo para os anos de 1988, 1995 e 2003. Esses mapas foram produzidos, utilizando-se imagens do satélite Lansat-5. As classes de cobertura aqui utilizadas foram aquelas mesmas utilizadas por Silva (2007) para os mapas correspondentes à área total do município de Sorocaba: pasto, VNR/ref (Vegetação Natural Remanescente + reflorestamento, o reflorestamento foi aqui incluido junto a VNR por ocorrer de forma muito pouco expressiva no município), área urbana, culturas, solo exposto, corpos d’água e outros. Todos os detalhes do processamento de imagens e etapas de elaboração dos mapas de cobertura do solo são descritas em Silva (2005).

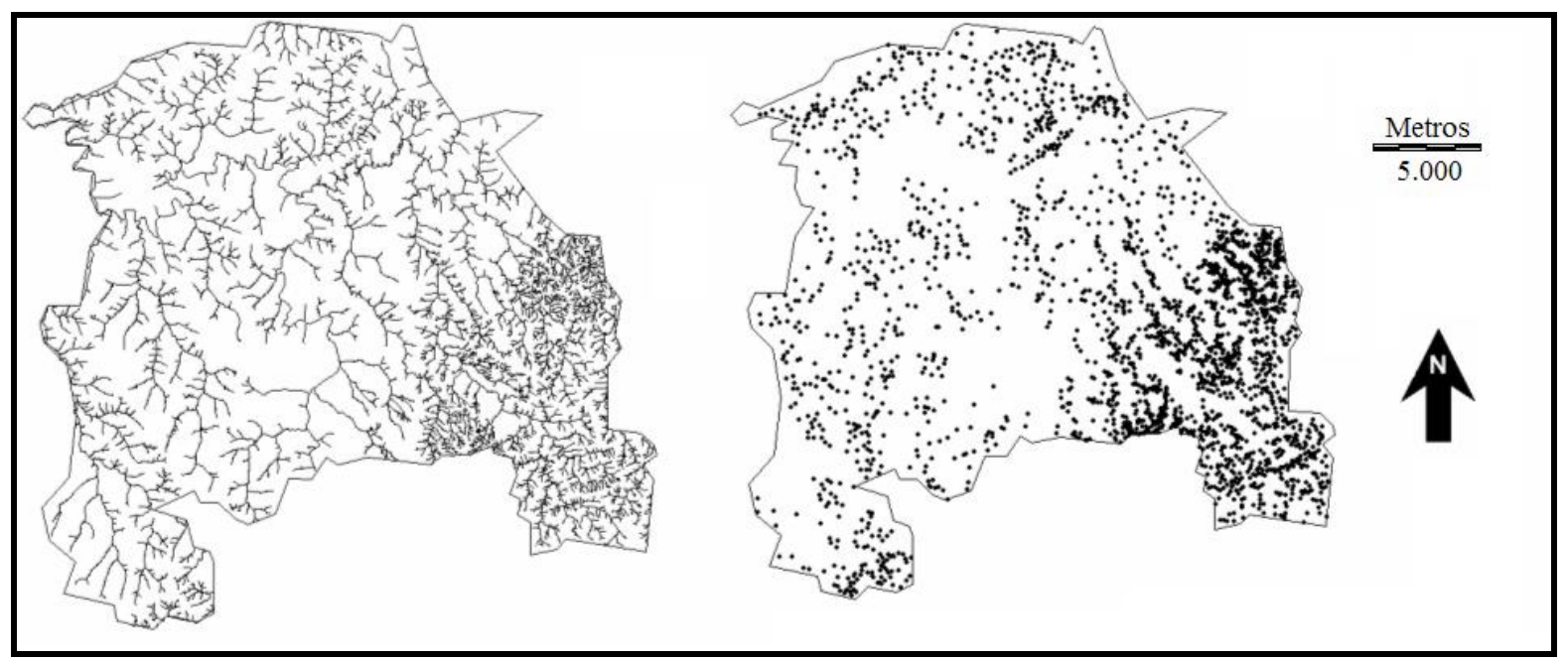

Figura 2. Mapas contendo a hidrografia (esquerda) e as cabeceiras (direita) ocorrentes ao longo da área de estudo. Fonte Silveira (2006). 
SILVA, A. M.; SILVEIRA, F. M.; IKEMATSU, P.; PAUlA, F. P.; BOMBACK, M.; NOGUEIRA, D. P.; ALVES, S. H. Análise espaço-temporal da cobertura do solo em faixas de áreas de preservação permanentes (apps) no município de Sorocaba, SP, Brasil. Ambi-Agua, Taubaté, v. 4, n. 2, p. 147-155, 2009. (doi:10.4136/ambi-agua.94)

O mapa da hidrografia, em escala de 1:50.000, foi rasterizado e, em seguida, utilizou-se o mapa rasterizado para criar a faixa de APP. Essa etapa foi feita por meio do comando Buffer do Idrisi e a largura da faixa foi estipulada considerando-se a legislação ambiental brasileira em vigor, que estipula que, para cursos d'água com largura até 10 metros, a largura é de 30 metros. Trabalhou-se de forma similar no mapa das nascentes, isto é, o mapa foi também rasterizado. Através do comando Buffer e, utilizando-se o mapa rasterizado sobre as nascentes, gerou-se um novo mapa, este agora mostrando a APP de cada cabeceira que, conforme especificado na legislação brasileira, é de um raio de 50 metros.

Os mapas contendo as faixas de APP relativos à hidrografia e as cabeceiras foram então integrados num só mapa pelo comando Overlay do Idrisi, este chamado “APP-completo". Dessa forma, num único mapa ficaram representadas as APPs relativas aos cursos d'água e também as APPs das nascentes, para uso nas etapas seguintes. Esse mapa é um mapa booleano, em que as áreas de interesse (APP) possuem valor igual a 1 e as áreas fora desses limites possuem valor 0 (Eastman, 2004).

Na etapa seguinte, aplicou-se novamente o comando Overlay (opção multiplicação) a fim de gerar um novo mapa que apresenta a cobertura do solo somente para as APPs. Para essa operação, foram utilizados dois mapas: o mapa de cobertura do solo e o mapa chamado "APPcompleto”. Esse procedimento foi aplicado de forma idêntica para os três mapas de cobertura do solo, gerando, portanto, três novos mapas, apresentados a seguir.

Aplicando o comando Area do Idrisi nos mapas elaborados, obteve-se a área ocupada por cada classe de cobertura em cada época considerada. Dividindo essas áreas pelo valor da APP total, cujo valor está mencionado em Silveira (2006), encontrou-se a porcentagem ocupada por cada classe, possibilitando assim a análise espaço-temporal da zona ripária do município de Sorocaba.

\section{RESULTADOS E DISCUSSÃO}

A seguir estão apresentadas as informações obtidas nos cruzamentos dos mapas. A Figura 3 mostra as coberturas do solo nas APPs para os anos 1988, 1995 e 2003. A Tabela 1 mostra os percentuais de ocorrência de cada classe de cobertura para cada época estudada. Para os anos 1988 e 1995, a classe que predominou é a pastagem. Já para o ano 2003, a pastagem perdeu área significativa e a classe VNR/Ref foi a que predominou. As classes cultura e área urbana mostraram crescimento contínuo, embora o crescimento da classe cultura tenha sido muito mais expressivo entre 1995 e 2003.

Os mapas indicam uma ocorrência da classe VNR/ref, de certa forma concentrada, na porção sudeste da área de estudo. Isso ocorre pelo fato de que nessa região ocorre a Serra de São Francisco, sendo mais alta que o restante do município e com vertentes mais íngremes.

A classe solo exposto constitui uma classe transitória. Segundo Silva et al. (2007), esta classe ocorre principalmente na região de periferia urbana, correspondendo a setores de periferia do município com organização caótica e muitas vezes invadindo trechos de APP, caracterizando áreas de risco, dado o risco de haver enchentes e invasão das águas nas casas de quem ali mora. Na área rural, essa classe corresponde a áreas em fase de entressafra, onde o solo está sendo preparado para uma nova cultura.

Naturalmente, a categoria de maior interesse para fins de conservação é a VNR/ref por ser a categoria que deveria ocorrer em $100 \%$ das faixas de APP segundo a legislação brasileira. Verifica-se que, felizmente, essa classe apresentou aumento ao longo da época analisada. 
SILVA, A. M.; SILVEIRA, F. M.; IKEMATSU, P.; PAULA, F. P.; BOMBACK, M.; NOGUEIRA, D. P.; ALVES, S. H. Análise espaço-temporal da cobertura do solo em faixas de áreas de preservação permanentes (apps) no município de Sorocaba, SP, Brasil. Ambi-Agua, Taubaté, v. 4, n. 2, p. 147-155, 2009. (doi:10.4136/ambi-agua.94)
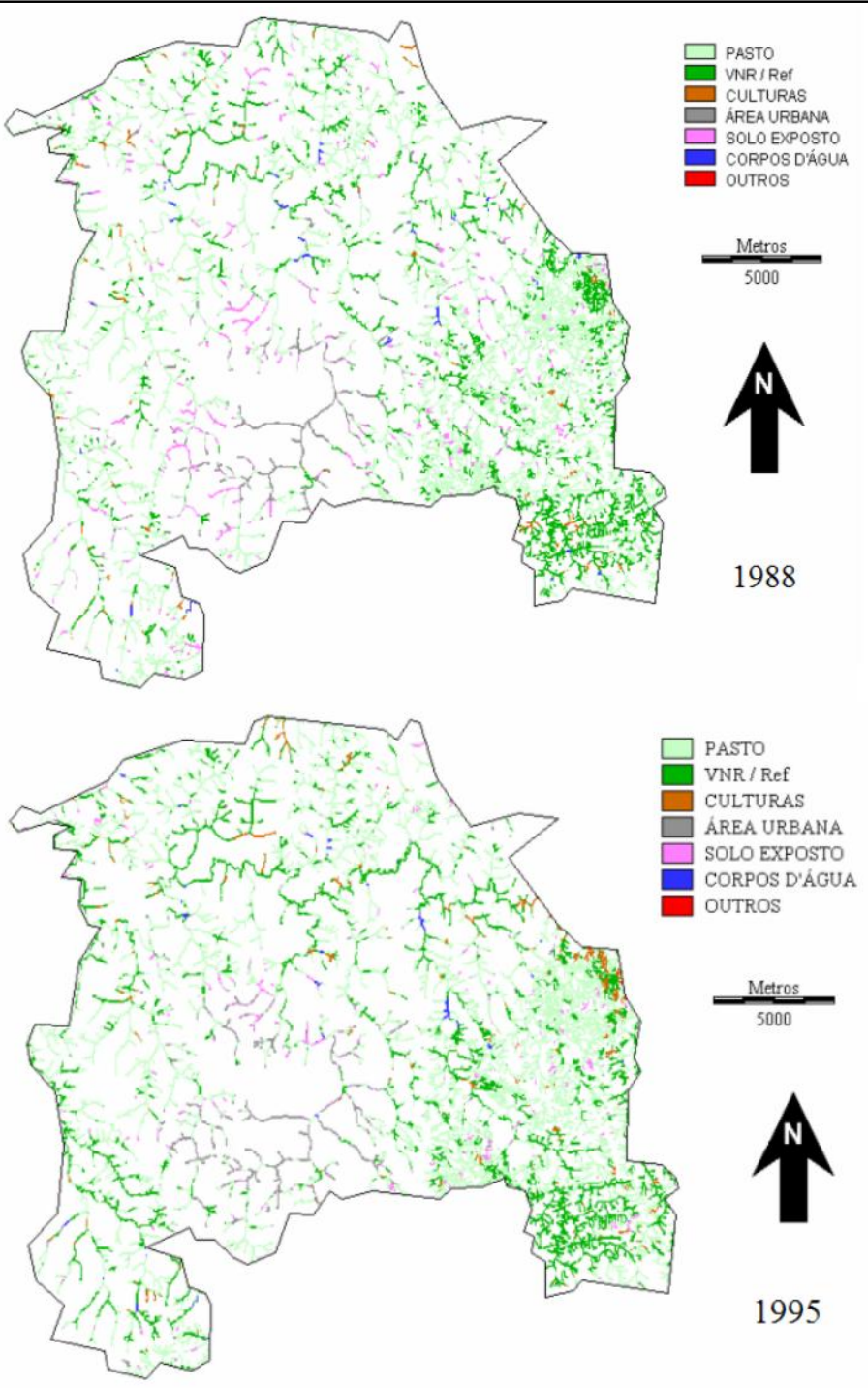

1988

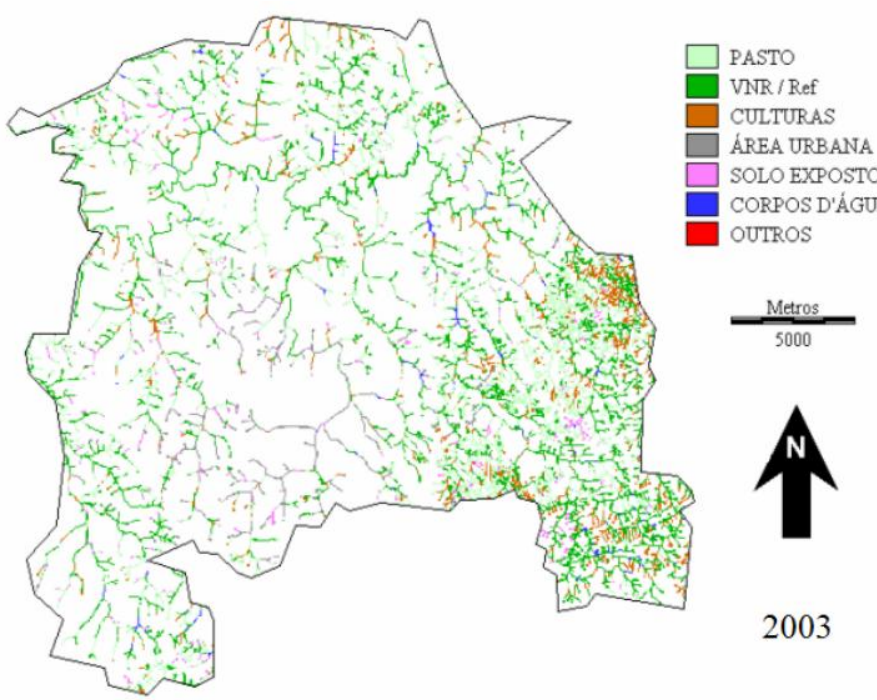

Figura 3. Distribuição das classes de cobertura do solo para as faixas de APP nos anos de 1988, 1995 e 2003.

Quanto à cobertura nas APPs relativas exclusivamente nas cabeceiras, verifica-se que a situação foi um pouco diferente, havendo diminuição da porcentagem entre 1988 e 1995 e no intervalo entre 1995 e 2003 voltou a aumentar (Tabela 2). Nota-se que o percentual de ocorrência da classe VNR/ref é baixo, ficando abaixo dos $30 \%$ em todas as épocas. O 
SILVA, A. M.; SILVEIRA, F. M.; IKEMATSU, P.; PAUlA, F. P.; BOMBACK, M.; NOGUEIRA, D. P.; ALVES, S. H. Análise espaço-temporal da cobertura do solo em faixas de áreas de preservação permanentes (apps) no município de Sorocaba, SP, Brasil. Ambi-Agua, Taubaté, v. 4, n. 2, p. 147-155, 2009. (doi:10.4136/ambi-agua.94)

principal problema associado à falta da vegetação natural na região de cabeceira dos córregos é relacionado ao controle da erosão nessas regiões e à questão hidrológica (produção regular de água), uma das sua principais funções (Allan, 2004).

Tabela 1. Porcentagem ocupada pelas classes de cobertura na faixa de APP (completa) nas épocas consideradas.

\begin{tabular}{cccc}
\hline \multirow{2}{*}{ Classe de cobertura } & \multicolumn{3}{c}{ Porcentagem de ocorrência } \\
\cline { 2 - 4 } & $\mathbf{1 9 8 8}$ & $\mathbf{1 9 9 5}$ & $\mathbf{2 0 0 3}$ \\
\hline Pasto & 60,20 & 57,26 & 32,77 \\
VNR / Ref & 26,17 & 31,09 & 41,57 \\
Culturas & 1,96 & 3,29 & 12,71 \\
Área urbana & 4,15 & 4,60 & 5,91 \\
Solo exposto & 6,66 & 3,06 & 5,33 \\
Corpos d’água & 0,83 & 0,68 & 1,70 \\
Outros & 0,03 & 0,02 & 0,01 \\
\hline
\end{tabular}

Tabela 2. Porcentagem ocupada pelas classes de cobertura na APP correspondente aos 50 metros de raio nas nascentes, nas épocas consideradas.

\begin{tabular}{ccrr}
\hline \multirow{2}{*}{ Classe de cobertura } & \multicolumn{3}{c}{ Porcentagem de ocorrência } \\
\cline { 2 - 4 } & $\mathbf{1 9 8 8}$ & $\mathbf{1 9 9 5}$ & $\mathbf{2 0 0 3}$ \\
\hline Pasto & 64,07 & 69,78 & 43,79 \\
VNR / Ref & 24,56 & 18,46 & 27,25 \\
Culturas & 1,80 & 2,72 & 14,45 \\
Área urbana & 2,74 & 3,72 & 6,07 \\
Solo exposto & 6,59 & 5,21 & 8,09 \\
Corpos d'água & 0,20 & 0,03 & 0,34 \\
Outros & 0,04 & 0,08 & 0,00 \\
\hline
\end{tabular}

A Tabela 3 mostra os valores de correlação para os dados de cada época (1988, 1995 e 2003) entre os percentuais de ocorrência de cada classe de cobertura para a área total com a faixa de APP e também entre a área total e a área de APP para as cabeceiras. Todos os valores de correlação revelaram-se altamente significativos. Isso mostra que, embora haja uma variação nas porcentagens de ocorrência de cada classe de cobertura entre as épocas estudadas, existe uma associação entre o uso do solo da área total do município e as áreas de preservação permanente em todas as épocas estudadas, mesmo existindo a lei que limite o uso da terra nessa faixa de terra.

Tabela 3. Valores de correlação entre o parâmetro cobertura do solo (área total) e os parâmetros cobertura das cabeceiras e cobertura das APPs (completa), conforme as respectivas épocas investigadas.

\begin{tabular}{cccc}
\hline Época & Parâmetro & cabeceiras & APPs (completa) \\
\hline 1988 & Cobertura do solo & 0,98 & 0,98 \\
1995 & Cobertura do solo & 0,98 & 0,95 \\
2003 & Cobertura do solo & 0,80 & 0,92 \\
\hline
\end{tabular}

Os mapas aqui apresentados, em três épocas, constituem uma forma interessante de investigação, pois, embora alguns serviços ecossistêmicos possam ser restabelecidos com a revegetação, alguns impactos, especialmente aqueles de natureza geomorfológica, são praticamente impossíveis de serem corrigidos, persistindo o que Harding et al. (1998 apud 
SILVA, A. M.; SILVEIRA, F. M.; IKEMATSU, P.; PAUlA, F. P.; BOMBACK, M.; NOGUEIRA, D. P.; ALVES, S. H. Análise espaço-temporal da cobertura do solo em faixas de áreas de preservação permanentes (apps) no município de Sorocaba, SP, Brasil. Ambi-Agua, Taubaté, v. 4, n. 2, p. 147-155, 2009. (doi:10.4136/ambi-agua.94)

Allan, 2004) chamaram de “o fantasma de usos passados do solo", que podem ser investigados sob a forma de mapas passados de cobertura do solo.

Visando à revegetação em áreas desprovidas de vegetação nas faixas de APP ao longo dos cursos d’água localizados no município de Sorocaba, o primeiro passo, que é identificar as áreas carentes de vegetação ciliar, já foi dado e os dados são aqui apresentados. Considerando o mapa de 2003 como o mapa atual por ser o mais recente dentre os analisados, verificou-se que 58,4\% da área investigada necessitam de revegetação. Isso significa que há a necessidade de reflorestar cerca de 5.400 hectares de APP.

Uma análise posterior poderia ser realizada para eleger áreas que poderiam ser primeiramente atendidas, principalmente no sentido de restabelecer a conexão de fragmentos florestais e realmente exercerem a função de corredores para a fauna local. Embora áreas já urbanizadas sejam, por exemplo, locais muito difíceis de efetivar-se a revegetação, dado o fato de normalmente existirem obras de infra-estrutura civil nesses locais (construções e estradas, por exemplo), áreas contendo cobertura de pastagem, solo exposto e culturas poderiam ser áreas prioritárias para tal finalidade.

\section{CONCLUSÕES}

Considerando o mapa de 2003, aproximadamente 58,4\% da faixa de APP ao longo dos cursos d’água necessitam de revegetação por estarem desprovidos desse tipo de cobertura.

O comportamento de ocorrência de vegetação natural ao longo dos cursos d'água não foi o mesmo, e para a região de nascentes, houve um acréscimo contínuo do percentual de ocorrência da classe VNR/ref entre as épocas estudadas. Já para as faixas ao longo dos cursos d’água, houve uma diminuição e, em seguida, o percentual aumentou.

\section{AGRADECIMENTOS}

Os autores agradecem à FAPESP pelo apoio financeiro (Processos 04/13096-7, 04/15796-6, e 05/56235-0) e ao Campus de Sorocaba da UNESP, pelo apoio logístico.

\section{REFERÊNCIAS}

ALLAN, J. D. Landscapes and Riverscapes: the influence of land use on stream ecosystems. Annual Review of Ecology, Evolution and Systematics, v. 35, p. 257 - 284, 2004.

EMPRESA BRASILEIRA DE PESQUISA AGROPECUÁRIA EMBRAPA. Banco de Dados Climatológicos. Disponível em: < www.bdclima.cnpm.embrapa.br $>$. Acesso em: julho de 2007.

EASTMAN, R. Idrisi GIS software - user’s manual. Worcester: Clark University, 2004.

GERGEL, S. E.; TURNER, M. G.; MILLER, J. R.; MELACK, J. M.; STANLEY, E. H. Landscape indicators of human impacts to riverine systems. Aquatic sciences, v. 64, p. $118-128,2002$.

INSTITUTO BRASILEIRO DE GEOGRAFIA E ESTATÍSTICA IBGE. Cid@des: o Brasil município por município. Disponível em: <www.ibge.gov.br>. Acesso em: julho de 2007. 
SILVA, A. M.; SILVEIRA, F. M.; IKEMATSU, P.; PAULA, F. P.; BOMBACK, M.; NOGUEIRA, D. P.; ALVES, S. H. Análise espaço-temporal da cobertura do solo em faixas de áreas de preservação permanentes (apps) no município de Sorocaba, SP, Brasil. Ambi-Agua, Taubaté, v. 4, n. 2, p. 147-155, 2009. (doi:10.4136/ambi-agua.94)

MATTOS, A. D.; JACOVINE, L. A. G.; VALVERDE, S. R.; SOUZA, A. L.; SILVA, M. L.; LIMA, J. E. Valoração ambiental de áreas de preservação permanente da microbacia do Ribeirão São Bartolomeu no município de Viçosa, MG. Revista Árvore, v. 31, n. 2, p. 347 - 353, abr. 2007.

MELO, A. C. G.; MIRANDA, D. L. C.; DURIGAN, G. Cobertura de copas como indicador de desenvolvimento estrutural de reflorestamentos de restauração de matas ciliares no médio vale do Paranapanema, SP, Brasil. Revista Árvore, v. 31, n. 2, p. 321 - 328, 2007.

NAIMAN, R. J.; DÉCAMPS, H. The ecology of interfaces: Riparian Zones. Annual Review of Ecology and Systematics, v. 28, p. 621 - 658, 1997.

NARUMALANI, S.; ZHOU, Y.; JENSEN, J. R. Application of remote sensing and geographic information systems to the delineation and analysis of riparian buffer zones. Aquatic Botany, v. 58, n. 3/4, p. 393-409, 1997.

OLIVEIRA, J. B.; CAMARGO, M. N.; ROSSI, M.; CALDERANO FILHO, B. Mapa Pedológico do Estado de São Paulo. Legenda Expandida. Campinas: Instituto Agronômico; Rio de Janeiro: EMBRAPA - Solos, 64 p., 1999.

PAUL, M. J.; MEYER, J. L. Streams in the Urban Landscape. Annual Review of Ecology, Evolution and Systematics, v. 32, p. 333 - 365, 2001.

POOLE, G. C. Fluvial landscape ecology: addressing uniqueness within the river discontinuum. Freshwater Biology, v. 47, p. 641 - 660, 2002.

FUNDAÇÃO SISTEMA ESTADUAL DE ANÁLISE DE DADOS SEADE. Anuário estatístico do Estado de São Paulo. Disponível em: <www.seade.gov.br>. Acesso em: julho de 2007.

SILVA, A. M. Cobertura do solo do município de Sorocaba-SP e implicações na fragmentação dos remanescentes florestais. Revista de Estudos Ambientais, v. 7, p. 38-46, 2005.

SILVA, A. M.; NALON, M. A.; KRONKA, F. J. N.; ALVARES, C. A.; CAMARGO, P. B.; MARTINELLI, L. A. Historical land-cover and use in different slopes and riparian buffer zones land uses in seven major watersheds of the State of São Paulo (Brazil). Scientia Agricola, v. 64, p. 325-335, 2007.

SILVA, A. M. Diagnóstico do processo erosivo ocorrente no município de Sorocaba (SP) dentro do quadro atual de uso da terra e previsão para cenários futuros. Relatório de Projeto Científico (Processos Fapesp 2004/15796-6 e 2004/13096-7), 2007. Disponível em: <http://www.bv.fapesp.br/projetos-jovens-pesquisadores/1434/diagnostico-processoerosivo-ocorrente-municipio-sorocaba/>. Acesso em julho de 2007.

SILVEIRA, F. M. Análise espaco-temporal de fragmentos na zona ripária ao longo dos cursos d’água no município de Sorocaba-SP. Relatório de bolsa de Iniciação Científica (Processo FAPESP 2005/56235-0), 2006. 